\title{
Catheter-associated urinary tract infection: why do not we control this adverse event?
}

\author{
Infecção do trato urinário associada a cateter vesical: por \\ que não controlamos esse evento adverso? \\ Infección del tracto urinario asociada con catéter vesical: \\ ¿por qué no controlamos ese evento adverso?
}

How to cite this article:

Mota EC, Oliveira AC. Catheter-associated urinary tract infection: why do not we control this adverse event? Rev Esc Enferm USP. 2019;53:e03452. DOI: http://dx.doi.org/10.1590/S1980-220X2018007503452

\author{
Écila Campos Mota ${ }^{1}$ \\ Adriana Cristina Oliveira ${ }^{2}$ \\ 1 Instituto Federal do Norte de Minas \\ Gerais, Araçuaí, MG, Brazil. \\ ${ }^{2}$ Universidade Federal de Minas Gerais, \\ Belo Horizonte, MG, Brazil.
}

\begin{abstract}
Objective: To identify factors related to the occurrence of urinary tract infection associated with urinary catheter use. Method: A longitudinal, retrospective cohort study carried out by analyzing the electronic medical records of patients admitted to an intensive care unit of a high-complexity hospital from July 2016 to June 2017. Demographic and clinical data were analyzed by descriptive and analytical analysis. Results: The incidence density of urinary tract infection related to urinary catheter use was 4.8 per 1000 catheters/day, the majority $(80.6 \%)$ with no indication for catheter use, and there was no prescription for insertion and/or maintenance in $86.7 \%$. The mean time between catheter insertion and infection diagnosis was $11.3 \pm 6.3$ days ( 6 to 28 days). Statistically significant factors $(p<0.001)$ related to urinary infection linked to catheter use were hospitalization time in the unit $(16.7 \pm 9$ days), catheter permanence time (12.7 \pm 6.9 days), and the use of antimicrobials in the intensive care unit $(8.6 \pm 6.3$ days). Conclusion: The association of indication absence and the record of the need for maintenance possibly potentiated the occurrence of urinary tract infection associated to catheter use.
\end{abstract}

DESCRIPTORS

Urinary Catheters; Catheter-Related Infections; Patient Safety; Infection Control.
Corresponding author:

Écila Campos Mota

Av. Corinto Crisóstomo Freire, 600, Apto.

207, Bloco Hortênsias, Morada do Parque

CEP 39401-365 - Montes Claros, MG, Brazil ecilacampos@hotmail.com
Received: 03/14/2018

Approved: 08/27/2018 


\section{INTRODUCTION}

Urinary tract infection (UTI) is one of the most prevalent health care-related infections, accounting for approximately $30 \%$ of intensive care unit (ICU) reports because of its relationship to urinary catheterization, but has great preventive potential ${ }^{(1-3)}$.

Approximately $80 \%$ of healthcare-related UTIs are associated with urinary catheter (UC) use. The risk of developing a catheter-associated UTI (CAUTI) increases with the duration of catheterization, and may reach 5\% with each day of use. Thus, it is estimated that this risk rises to $100 \%$ after 28 days of catheterization, culminating in approximately $4 \%$ of patients with evolution from secondary sepsis to infection and an estimated mortality rate of up to $30 \%^{(3-4)}$.

Several strategies to prevent the occurrence of CAUTI have been considered, all of which point to a fundamental principle: restricted indication, performed according to guideline recommendations, insertion with aseptic technique, care in maintenance and rigor regarding the permanence time of the $\mathrm{UC}^{(2,5-8)}$. Despite these recommendations, UC use is still considered variable with little or no control, thereby affecting high CAUTI rates, presenting important morbidity and mortality, increased hospitalization time and

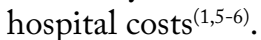

Subjectivity in the indication and keeping it longer than necessary have been described in clinical practice and strongly contribute to the occurrence of CAUTI, which can be considered avoidable adverse events. Thus, it is necessary to identify the gaps in this practice to improve the practice regarding use of urinary catheters and their occurrence in order to carry out timely interventions and modified habits of professionals and expectations about the need for a urinary catheter. It is also necessary to reinforce the importance of multidisciplinary communication in a continuous and consistent manner. Catheter indication should be an activity of the attending physician, but must be known by all care staff. Its maintenance involves participation by a multidisciplinary team to collaborate with the medical team to evaluate the necessity of their permanence, thus guaranteeing the safety of the patient, the team and the institution ${ }^{(6)}$.

In view of the aforementioned, this study aimed to identify the factors related to the occurrence of CAUTI.

\section{METHOD}

\section{Study DESIGN}

An epidemiological, longitudinal, retrospective cohort study.

\section{Study SCEnARIO}

The study was carried out in an ICU for adult patients of a high-complexity philanthropic hospital with 321 beds, and $80 \%$ of the services performed by the Unified Health System (SUS - Sistema Único de Saúde) in the state of Minas Gerais. The ICU is composed of 10 beds, with a monthly average of 36 admissions and an average stay time of 8.6 days. Approximately $95 \%$ of patients admitted to the unit used UC.

\section{SelECTION CRITERIA}

Patients with UC for more than 24 hours, older than 18 years and had no diagnosis of UTI upon admission were included.

\section{Data COLleCTION}

Data collection was by convenience sampling from July to September 2017 and was carried out by the researcher (who has extensive experience in the diagnostic criteria of CAUTI) through a retrospective analysis of the electronic medical record. The medical and statistical file of the hospital was requested to access all medical records of patients admitted to the ICU from July 2016 to June 2017, and included patients with UC for more than 24 hours, older than 18 years old, and who did not have a UTI diagnosis at admission.

A semi-structured instrument was used to evaluate demographic data such as gender and age, as well as clinical data such as treatment specialization upon admission, indication of UC use, permanence length of UC, CAUTI diagnosis, use of antimicrobials during hospitalization in the unit, isolated microorganisms in the urinalysis and sensitivity profile, hospitalization time in the unit and in the hospital, and the outcome (discharge, transfer or death).

The criteria implemented to define CAUTI was from the National Healthcare Safety Network (NHSN), which consists in $^{(9)}$ : patients undergoing catheterization for more than 48 hours or after catheter removal within 48 hours, fever $\left(\geq 38^{\circ} \mathrm{C}\right)$ and positive urinalysis with no more than two species of microorganisms with growth $\geq 10^{5}$ colony forming units per $\mathrm{ml}$ of urine $(\mathrm{CFU} / \mathrm{ml})$.

Adequate indications for $\mathrm{UC}$ insertion were those described by the Centers for Disease Control and Prevention (CDC), according to which patients with acute urinary retention or bladder obstruction should undergo the procedure; in surgeries in which diuresis control is necessary; in the postoperative period of urological surgeries up to 24 to 48 hours and long-term surgeries; submitted to urological surgeries or involving structures contiguous to the genitourinary tract; incontinent with sacral or perineal ulcers; terminal patients, to provide comfort; and those with a long period of bed rest due to trauma to the spine, waist or pelvis ${ }^{(2)}$. The registered indications (description of the catheterization reason in the patient's chart) or presumed (when it is possible to evaluate the reason for catheterization by clinical data and the patient's diagnosis even without registration).

For the evaluation of microorganisms isolated in urinalysis, only those that were epidemiologically important were considered according to the Clinical and Laboratory Standards Institute (CLSI) ${ }^{(10)}$.

The calculation of the CAUTI incidence density was performed by the following formula, according to the $\mathrm{NHSN}^{(9)}$ : 
CAUTI incidence density $=$

Total number of CAUTI, in the surveillance period

Number of patients with UC-day,in the surveillance period

\section{DATA ANALYSIS AND PROCESSING}

Descriptive analysis of the data, Pearson's chi-square test or Fisher's exact test and Mann-Whitney test were performed in the Statistical Package for Social Sciences (SPSS), version 23.0 .

\section{ETHICAL ASPECTS}

The research complied with all the recommendations of Resolution no. 466/2012 of the National Health Council and was approved by the Research Ethics Committee of the Federal University of Minas Gerais under opinion 2.069.140/2017. A clear and Informed Consent Form was not necessary as it was a survey of secondary data and because the access was in electronic medical records (without direct contact with the patient).

\section{RESULTS}

There were 432 patients admitted to the ICU during follow-up; of these, 402 (93.3\%) used UC for more than 24 hours, thereby constituting the study sample. The mean age of the patients was 50.6 years (median 50 ), with a standard deviation of \pm 18.8 , and $56.7 \%$ were male. The mean hospitalization time of patients in the hospital and ICU was 30 and 8.6 days, respectively.

The majority of patients admitted to the ICU came from the emergency room (43.8\%) for surgical (56.2\%) and/or clinical $(43.8 \%)$ specializations. The surgical specialization with the greatest number of hospitalizations was neurological surgery (52.2\%), and general clinical (52.2\%). Moreover, $87.3 \%$ of the patients used antimicrobials during ICU stay to treat infections not associated with the objective of this study for an average of 5.3 days. Regarding the evolution, $60.2 \%$ were transferred to semi-intensive units or infirmaries, $35.8 \%$ evolved to death, and $4 \%$ were discharged from hospital. Table 1 shows the characteristics related to the use of UC in the ICU.

No registry of catheter replacement or reintegration into ICU admission was observed, even if inserted in another location outside the hospital units.

The site which presented the highest non-conformity index regarding the appropriate indication for UC insertion was the infirmary (94.3\%). All the indications considered adequate for $\mathrm{UC}$ use in patients admitted to the ICU were presumed, and most were not prescribed. Only four $(7.7 \%)$ of the prescribed catheters were presumably adequate.

The number of patients with catheter/day in the surveillance period was 3,080 , the CAUTI incidence density was 4.87 per $1,000 \mathrm{UC} /$ day, and $80.0 \%$ of the patients who developed infection had no indication for UC use, while $86.7 \%$ had no prescription for insertion and/or maintenance.
Table 1 - Descriptive analysis of the variables related to urinary catheter use in the intensive care unit - Montes Claros, MG, Brazil, June 2016 to July 2017.

\begin{tabular}{|c|c|}
\hline Variables & n $(\%)$ \\
\hline \multicolumn{2}{|l|}{ Location of catheter insertion $(n=402)$} \\
\hline Surgical ward & $170(42.3)$ \\
\hline Emergency ward & $70(17.4)$ \\
\hline Intensive care unit & $30(7.5)$ \\
\hline Infirmary & $70(17.4)$ \\
\hline Other locations outside hospital units & $62(15.4)$ \\
\hline \multicolumn{2}{|l|}{ Professional who inserted the catheter $(n=402)$} \\
\hline Nursing technician & $283(70.4)$ \\
\hline Nurse & $34(8.5)$ \\
\hline Doctor & $15(3.7)$ \\
\hline No record & $70(17.4)$ \\
\hline \multicolumn{2}{|l|}{ Prescription of catheter insertion $(n=402)$} \\
\hline Yes & $52(12.9)$ \\
\hline No & $350(87.1)$ \\
\hline \multicolumn{2}{|l|}{ Indication for use of the catheter $(n=402)$} \\
\hline Yes & $78(19.4)$ \\
\hline No & $324(80.6)$ \\
\hline \multicolumn{2}{|l|}{ Type of indication suitable for catheter use $(n=78)$} \\
\hline Presumed & $78(100)$ \\
\hline Recorded & $0(0)$ \\
\hline \multicolumn{2}{|l|}{$\begin{array}{l}\text { Description of the presumed indication for insertion of } \\
\text { the catheter }(n=78)\end{array}$} \\
\hline Patient underwent urological surgery & $31(39.7)$ \\
\hline Patient immobilized due to trauma & $19(24.4)$ \\
\hline Terminal patient to provide comfort & $12(15.4)$ \\
\hline Incontinent patients with sacral or perineal ulcers & $6(7.7)$ \\
\hline Patient with inability to spontaneously urinate & $5(6.4)$ \\
\hline Long-term surgery & $5(6.4)$ \\
\hline \multicolumn{2}{|l|}{ Urinalysis performed $(n=402)$} \\
\hline Yes & $141(35.1)$ \\
\hline No & $261(64.9)$ \\
\hline \multicolumn{2}{|l|}{ Result of the urinalysis $(n=141)$} \\
\hline Positive & $25(17.7)$ \\
\hline Negative & $116(82.3)$ \\
\hline \multicolumn{2}{|l|}{$\begin{array}{l}\text { Microorganism identified in urinalysis of the catheter } \\
(\mathbf{n}=25)\end{array}$} \\
\hline Klebsiella pneumoniae & $10(40.0)$ \\
\hline Escherichia coli & $4(16.0)$ \\
\hline Pseudomonas aeruginosa & $3(12.0)$ \\
\hline Acinetobacter baumannii & $2(8.0)$ \\
\hline Enterococcus $S P$ & $1(4.0)$ \\
\hline Others & $5(20.0)$ \\
\hline \multicolumn{2}{|l|}{ Multiresistant microrganisms $(n=25)$} \\
\hline Yes & $9(36.0)$ \\
\hline No & $16(64.0)$ \\
\hline \multicolumn{2}{|c|}{$\begin{array}{l}\text { Diagnosis of catheter-associated urinary tract infection } \\
(n=402)\end{array}$} \\
\hline Yes & $15(3.7)$ \\
\hline No & $387(96.3)$ \\
\hline
\end{tabular}


Of the 141 patients who performed urinalysis, $70.9 \%$ had previously used antibiotics for at least 24 hours in the ICU. Regarding the CAUTI etiological agent, Klebsiella pneumoniae (46.7\%), Escherichia coli (20.0\%), Pseudomonas aeruginosa (13.3\%), Acinetobacter baumannii (13.3\%) and Enterococcus sp (6.7\%) were identified. All multiresistant microorganisms identified in urinalysis were associated with CAUTI, namely: K. pneumoniae (44.5\%), E. coli (22.2\%), $P$. aeruginosa (11.1\%), A. baumannii (11.1\%) and Enterococcus sp (11.1\%). Table 2 shows the comparison of the patients regarding the CAUTI diagnosis according to sociodemographic and clinical factors.

Table 2 - Comparison of sociodemographic and clinical factors of patients admitted to the intensive care unit with and without urinary tract infection diagnosis - Montes Claros, MG, Brazil, from June 2016 to July 2017.

\begin{tabular}{|c|c|c|c|}
\hline \multirow{2}{*}{ Variables } & \multicolumn{2}{|c|}{$\begin{array}{l}\text { Catheter-associated } \\
\text { Urinary Tract } \\
\text { Infection }\end{array}$} & \multirow{2}{*}{ P-Value } \\
\hline & $\begin{array}{c}\text { Yes } \\
\text { n }(\%)\end{array}$ & $\begin{array}{c}\text { No } \\
\text { n }(\%)\end{array}$ & \\
\hline \multicolumn{4}{|l|}{ Gender } \\
\hline Female & $7(4.0)$ & $167(96.0)$ & $0.788^{*}$ \\
\hline Male & $8(3.5)$ & $220(96.5)$ & \\
\hline \multicolumn{4}{|l|}{ Age range, years } \\
\hline$<60$ & $9(3.3)$ & $263(96.7)$ & $0.518^{*}$ \\
\hline$\geq 60$ & $6(4.6)$ & $124(95.4)$ & \\
\hline \multicolumn{4}{|l|}{ Location of catheter insertion } \\
\hline Surgical ward & $9(5.3)$ & $161(94.7)$ & $0.228^{+}$ \\
\hline Emergency ward & $4(5.7)$ & $66(94.3)$ & \\
\hline Intensive care unit & $0(0)$ & $30(100)$ & \\
\hline Infirmary & $2(2.9)$ & $68(97.1)$ & \\
\hline $\begin{array}{l}\text { Other locations outside hospital } \\
\text { units }\end{array}$ & $0(0)$ & $62(100)$ & \\
\hline \multicolumn{4}{|c|}{ Length of stay in the intensive care unit, days } \\
\hline Mean \pm standard deviation & $16.7 \pm 9.0$ & $7.7 \pm 8.5$ & $<0.001^{\ddagger}$ \\
\hline Median & $16(4-32)$ & $5(1-68)$ & \\
\hline \multicolumn{4}{|l|}{ Hospitalization time, days } \\
\hline Mean \pm standard deviation & $75.8 \pm 68.6$ & $28.2 \pm 30.6$ & $0.001^{\ddagger}$ \\
\hline Median & $33(7-242)$ & $19(1-222)$ & \\
\hline \multicolumn{4}{|l|}{ Catheter permanence time, days } \\
\hline Mean \pm standard deviation & $12.7 \pm 6.9$ & $6.9 \pm 7.3$ & $<0.001^{*}$ \\
\hline Median & $12(4-30)$ & $4(1-68)$ & \\
\hline \multicolumn{4}{|l|}{ Indication for use of the catheter } \\
\hline Yes & $3(3.8)$ & $95(96.2)$ & $0.583^{+}$ \\
\hline No & $12(3.7)$ & $312(96.3)$ & \\
\hline \multicolumn{4}{|c|}{ Use of antimicrobials in the intensive care unit } \\
\hline Yes & $14(4.0)$ & $337(96.0)$ & $0.411^{+}$ \\
\hline No & $1(2.0)$ & $50(98.0)$ & \\
\hline \multicolumn{4}{|c|}{ Days of antimicrobial use in the intensive care unit } \\
\hline Mean \pm standard deviation & $8.6 \pm 6.3$ & $5.2 \pm 6.1$ & $0.019^{+}$ \\
\hline Median & $9(1-21)$ & $3(1-59)$ & \\
\hline \multicolumn{4}{|l|}{ Death } \\
\hline Yes & $2(1.4)$ & $142(98.6)$ & $0.09^{+}$ \\
\hline No & $13(5.0)$ & 245 (95.0) & \\
\hline
\end{tabular}

*Chi-squared test; + Fisher's exact test; $¥$ Mann-Whitney test. Note: $(n=402)$.
The UC duration was significantly associated with CAUTI. Figure 1 shows this relationship.

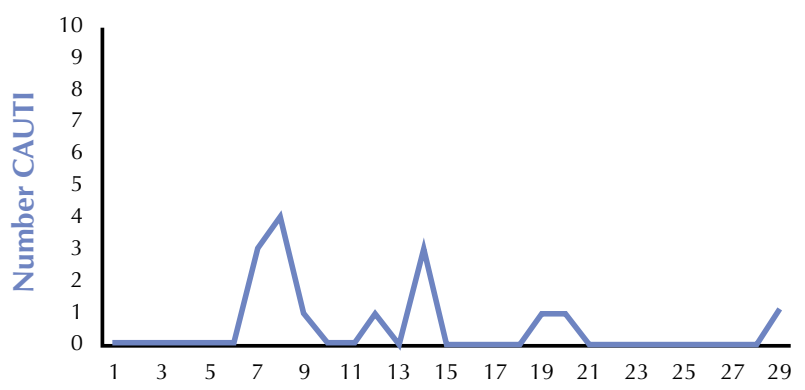

Figure 1 - Relationship between catheter retention time and catheter-associated urinary tract infection in patients admitted to the intensive care unit - Montes Claros, MG, Brazil, from June 2016 to July 2017.

The mean time between UC insertion and CAUTI diagnosis was 11.3 days (median: 8 ), with a standard deviation of \pm 6.3 (minimum of 6 and maximum of 28 days), and mean time between ICU hospitalization and the CAUTI diagnosis was 9.6 days (median: 7 ), with a standard deviation of \pm 5.6 (minimum of 4 and maximum of 26 days).

Although no significant difference was observed between the permanence time of the UC according to the insertion location $(p>0.05)$, the catheters inserted in the infirmary wards/apartments had a longer residence time (mean $9.8 \pm 10.5$; median of 7 , minimum of 1 and maximum of 68 days), compared to those inserted in the surgical ward (mean $5.7 \pm 6$, median of 3 , minimum of 1 and maximum of 32 days).

\section{DISCUSSION}

Urinary catheter use was considered inappropriate in $80.6 \%$ in relation to the indication and the evaluation of the necessity of its permanence. The CAUTI incidence density in the present study is within the range registered by the National Health Surveillance Agency (ANVISA - Agência Nacional de Vigilância Sanitária), which refers to indices of 3.1 to $7.4 / 1000$ catheters/day ${ }^{(8)}$. It should be considered that this rate may be underestimated even according to the intervals defined by ANVISA. This possibility is based on the fact that the criterion for defining CAUTI used in this study considers a positive urinalysis, a procedure registered in $35.1 \%$ of patients with UC, as well as clinical signs. Another interesting fact is that even though urinalysis was performed, a large part (70.9\%) of these patients used antibiotics prior to urinalysis, which certainly hinders the growth of microorganisms and provides false-negative results.

Although the CAUTI rate in the present study is comparable to the national data, it is higher when compared to records of international organizations. In a multicenter ICU study from 50 countries, The International Nosocomial Infection Control Consortium (INICC) recorded CAUTI incidence density of 3.9 per 1,000 catheters/day, and this rate was even lower (1.7 per 1,000 catheters/day) in ICUs of American hospitals in the CDC-NHSN report. The difference found between these two reports is associated to the possibility of its variation being 
related to the socioeconomic level of the country and to the experience in infection control and patient safety, which can strongly influence the CAUTI indicators ${ }^{(11-12)}$.

Regarding the sociodemographic and clinical factors of the patient which may increase the risk of CAUTI, advanced age and female gender are considered groups with higher predisposition $^{(2,13)}$. However, the CAUTI rates in this study were associated with clinical factors such as the UC permanence time and the patient's time in the ICU.

Most UCs were inserted by nursing technicians and without prescription and/or indication; when there was the indication, all were presumed by the researcher. Although the data point to the contrary of what is disseminated as a need for accurate and restricted indication of UC use, several studies corroborate this scenario in which catheters are often inserted without proper indication, and once inserted they are not reevaluated in time for them to be removed ${ }^{(4-6)}$. It should also be pointed out that the adequate indication for UC should be considered as the first step in CAUTI prevention, and that the risk of this adverse event (mostly avoidable) already shows greater probability of occurrence when this barrier is exceeded ${ }^{(2,5-7)}$.

After adequate indication, or lack of it, relevant CAUTI prevention and control mechanisms should still be observed daily, thereby highlighting the next aspect which refers to the UC duration. It should be evaluated in accordance with international recommendations, so that it remains in place for as short of a time as possible.

The majority of insertions performed in surgical patients did not have adequate indications (72.9\%), and the UC duration (mean of 5.7 days) was higher than indicated by the guidelines, which recommend the use of this device in specific surgeries and their removal as soon as possible postoperatively, preferably within 24 hours, unless there are other appropriate indications for their permanence ${ }^{(2,7-12)}$.

It is also important to evaluate the insertion conditions of the UC, especially in emergencies such as in the surgical ward, the emergency room and pre-hospital care. Although $\mathrm{UC}$ replacement at fixed intervals is not recommended, and the unit investigated does not have a UC exchange protocol inserted in emergency situations, the guidelines recommend this practice when there are failures in aseptic technique, disconnection or leakage, obstruction or if the system drainage system is compromised ${ }^{(2,7)}$.

In this sense, it is also important to highlight the actions necessary to reduce inappropriate use in terms of UC duration, how to recognize and notify its presence in the patient, to discuss the need for their maintenance with the medical staff daily and ensure prescription for its removal. Such actions have not been observed in clinical practice, and the result is maintaining high CAUTI rates caused by failures in multiprofessional care actions and ineffective communication resulting from the poor quality of the records. Studies point out that the catheter presence in the patient is unknown, inadequate practices, unsafe maintenance, lack of control and attention to the need for their permanence by the multiprofessional team as factors which drive the occurrence of CAUTI ${ }^{(4-6)}$.
Thus, nursing performance should play an important role in daily evaluation of UC permanence. The implementation of a nurse-oriented protocol effectively reduces CAUTI prevalence, and it is essential that these professionals feel empowered to (re)evaluate and discuss the need to maintain the UC, aiming at reducing their usage time ${ }^{(14)}$. The quality of CAUTI care and prevention programs is directly related to the adequate number of professionals to exercise care in order to promote safe care ${ }^{(6,15)}$. In the studied unit, the number of nursing professionals complies with the resolution of the Federal Nursing Council (COFEN - Conselho Federal de Enfermagem) for care provided to intensive care patients, not constituting a barrier in this process.

It is also worth noting that the insertion of the UC, defined by the normative opinion of COFEN, "is an activity that requires trained and qualified professionals because it is an invasive procedure which involves risks to the patient." Also, "it requires care of greater technical complexity and scientific knowledge, and for these reasons UC insertion is exclusively performed by the nurse in the scope of the nursing team", which reinforces its participation in the evaluation from its indication to the daily maintenance, as well as in the adopted practices in their handling ${ }^{(6,16)}$.

Guidelines for CAUTI prevention emphasize that the most effective and economic measures are to limit the use of urinary catheters to patients with clear indication and to remove them as soon as they are no longer needed ${ }^{(2,7-8)}$. The median time between UC insertion and CAUTI occurrence in this study was 8 days. Approximately $50.0 \%$ of the catheterized patients acquire infections after a short period of time (within 7 days), and the infection is practically inevitable after 28 days $^{(3)}$.

After UC insertion, the bacteria that colonize the urethral meatus adhere to the internal and/or external surface of the catheter and can initiate biofilm formation, considered the most important factor for CAUTI. Thus, in addition to catheter removal, there is no evidence of effective methods for prevention or control of biofilm formation ${ }^{(17-19)}$.

The main microorganisms which caused CAUTI in this investigation were the Gram-negative microorganisms such as $K$. pneumoniae and E. coli, identified as the most common etiological agents. The high prevalence of these bacteria is due to their motility, facilitating their ascension via intraor extraluminal of the $\mathrm{UC}^{(1,13)}$. In addition to $E$. coli, other microorganisms are strongly associated with CAUTI, such as Enterococcus spp, P. aeruginosa, Proteus mirabilis, $K$. pneumoniae and Enterobacter sp. ${ }^{(6)}$.

An important factor which aggravates the etiology of CAUTI is bacterial resistance. In this study, all multiresistant microorganisms identified in urinalysis were associated with CAUTI. Intensive care unit patients are at high risk for CAUTI caused by resistant bacteria, as many have changes in their immune system and receive broad spectrum antimicrobials, in addition to UC being an important reservoir of multiresistant microorganisms, causing serious infections, prolonged hospitalizations, high costs and higher mortality ${ }^{(3,17)}$.

Multiple-measure strategies have been pointed out as being possible to reduce the occurrence of CAUTIs when adopted 
simultaneously. However, their implementation requires changes which usually involve education, leadership commitment, and implementation of guidelines for indication and appropriate UC use ${ }^{(1,5,18,20-21)}$. Guaranteeing that all health care team members are aware that a patient has a UC is an important strategy for reducing CAUTI and ensuring quality in maintenance care and a daily assessment of their permanence ${ }^{(20-21)}$.

Regarding the evaluation of the records adopted in this study (the electronic records analysis), it is known that there may be an absence of information due to the lack of records by the professionals and the quality of the records, as well as physical records which also present these limitations.

\section{CONCLUSION}

The factors which were significantly associated to CAUTI were the length of hospital stay in the ICU and in the hospital, UC permanence time, and days of antimicrobial use in the ICU. The urinary catheter use was associated with high rates of urinary tract infections, but without indications and records justifying its use. All appropriate indications for UC use were presumed, which is an important indicator of failure in the work process not being systematized in terms of documentation, therefore posing a potential risk to patient safety.

\section{RESUMO}

Objetivo: Identificar fatores relacionados à ocorrência de infecção do trato urinário associada ao uso do cateter vesical. Método: Estudo longitudinal, coorte retrospectivo, realizado pela análise do prontuário eletrônico de pacientes admitidos em unidade de terapia intensiva de um hospital de alta complexidade, de julho de 2016 a junho de 2017. Avaliaram-se dados demográficos e clínicos, por análise descritiva e analítica. Resultados: A densidade de incidência da infecção urinária relacionada ao uso do cateter vesical foi de 4,8 por 1.000 cateter/dia, sendo a maioria $(80,6 \%)$ sem indicação para uso do cateter e, em $86,7 \%$, não havia prescrição para inserção e/ou manutenção. O tempo médio entre inserção do cateter vesical e diagnóstico de infecção foi de $11,3 \pm 6,3$ dias (6 a 28 dias). Os fatores estatisticamente significativos $(\mathrm{p}<0,001)$ relacionados à infecção urinária relacionada ao uso do cateter vesical foram tempo de internação na unidade (16,7 \pm 9 dias), tempo de permanência do cateter vesical $(12,7 \pm 6,9$ dias) e uso de antimicrobianos na unidade de terapia intensiva $(8,6 \pm 6,3$ dias). Conclusão: A associação da ausência da indicação e do registro da necessidade de manutenção possivelmente potencializou a ocorrência de infecção urinária relacionada ao uso do cateter vesical.

\section{DESCRITORES}

Cateteres Urinários; Infecções Relacionadas a Cateter; Segurança do Paciente; Controle de Infecções.

\section{RESUMEN}

Objetivo: Identificar factores relacionados con la ocurrencia de infección del tracto urinario asociado con el uso del catéter vesical. Método: Estudio longitudinal, de cohorte retrospectivo, realizado por análisis de la ficha electrónica de pacientes ingresados en unidad de cuidados intensivos de un hospital de alta complejidad, de julio de 2016 a junio de 2017. Se evaluaron los datos demográficos y clínicos, por análisis descriptivo y analítico. Resultados: La densidad de incidencia de la infección urinaria relacionada con el uso del catéter vesical fue de 4,8 por 1.000 catéter/día, siendo la mayoría (80,6\%) sin indicación para uso del catéter y, en el 86,7\%, no había prescripción para inserción y/o mantenimiento. El tiempo medio entre inserción del catéter vesical y diagnóstico de infección fue de $111,3 \pm 6,3$ días (6 a 28 días). Los factores estadísticamente significativos ( $p<0,001)$ relacionados con la infección urinaria relacionada con el uso del catéter vesical fueron tiempo de estancia hospitalaria en la unidad $(12,7 \pm 6,9$ días) y uso de antimicrobianos en la unidad de cuidados intensivos (8,6 $\pm 6,3$ días). Conclusión: La asociación de la ausencia de la indicación y del registro de la necesidad de mantenimiento posiblemente potenció la ocurrencia de infección urinaria relacionada con el uso del catéter vesical.

\section{DESCRIPTORES}

Catéteres Urinarios; Infecciones Relacionadas con Catéteres; Seguridad del Paciente; Control de Infecciones.

\section{REFERENCES}

1. Miranda AL, Oliveira AL, Nacer DT, Aguiar CA. Results after implementation of a protocol on the incidence of urinary tract infection in an intensive care unit. Rev Latino Am Enfermagem [Internet]. 2016 [cited 2018 Mar 3];24:e2804. Available from: http://www.scielo.br/ pdf/rlae/v24/0104-1169-rlae-24-02804.pdf

2. Gould CV, Umscheid CA, Agarwal RK, Kuntz G, Pegues DA; Healthcare Infection Control Practices Advisory Committee. Guideline for prevention of catheter-associated urinary tract infections, 2009. Infect Control Hosp Epidemiol. 2010:31(4):319-26. DOI: 10.1086/651091

3. Tenke P, Mezei T, Bode I, Koves B. Catheter-associated urinary tract infections. Eur Urol Suppl. 2017; 16(4):138-43. DOI: https://doi. org/10.1016/j.eursup.2016.10.001

4. Taleschian-Tabrizi N, Farhadi F, Madani N, Mokhtarkhani M, Kolahdouzan K, Hajebrahimi S. Compliance with guideline statements for urethral catheterization in an iranian teaching hospital. Int J Health Policy Manag. 2015;4(12):805-11. DOI: 10.15171/ijhpm.2015.128.

5. Saint S, Fowler KE, Sermak K, Gaies E, Harrod M, Holland P, et al. Introducing the no preventable harms campaign: creating the safest health care system in the world, starting with catheter-associated urinary tract infection prevention. Am J Infect Control. 2015;43(3):254-9. DOI: https://doi.org/10.1016/j.ajic.2014.11.016.

6. Meddings J, Rogers MA, Krein SL, Fakih MG, Olmsted RN, Saint S. Reducing unnecessary urinary Catheter use and other strategies to prevent catheter-associated urinary tract infection: An integrative review. BMJ Qual Safety. 2014;23(4):277-89. DOI: 10.1136/bmjqs-2012-001774.

7. Lo E, Nicolle LE, Coffin SE, Gould C, Maragakis LL, Meddings J, et al. Strategies to prevent catheter-associated urinary tract infections in acute care hospitals: 2014 update. Infect Control Hosp Epidemiol. 2014;5(35):464-79. DOI: 10.1086/675718.

8. Brasil. Ministério da Saúde; Agência Nacional de Vigilância Sanitária. Medidas de Prevenção de Infecção Relacionada à Assistência à Saúde [Internet]. Brasília, DF: ANVISA; 2017 [citado 2018 fev. 19]. Disponível em: http://portal.anvisa.gov.br/documents/33852/3507912/ Caderno+4+-+Medidas+de+Prevenção+de+Infecção+Relacionada+à+Assistência+à+Saúde/a3f23dfb-2c54-4e64-881c-fccf9220c373 
9. Centers for Disease Control and Prevention; National Healthcare Safety Network (NHSN). Patient Safety Component Protocol [Internet]. New York; 2017 [cited 2018 Feb 19]. Available from: https://www.cdc.gov/nhsn/pdfs/pscmanual/pcsmanual_current.pdf

10. Clinical and Laboratory Standards Institute (CLSI). M100-S25. Performance standards for antimicrobial susceptibility testing [Internet]. Wayne; 2015 [cited 2018 Feb 19]. Available from: http://jzx.cqrmhospital.com/upfiles/201601/20160112155335884.pdf

11. Rosenthal VD, Al-Abdely HM, El-Kholy AA, AIKhawaja SAA, Leblebicioglu H, Mehta Y, et al. International Nosocomial Infection Control Consortium report, data summary of 50 countries for 2010-2015: device-associated module. Am J Infect Control. 2016;44(12):1495-504.

12. Dudeck MA, Edwards JR, Allen-Bridson K, Gross C, Malpiedi PJ, Peterson KD, et al. National Healthcare Safety Network report, data summary for 2013: device-associated module. Am J Infect Control [Internet]. 2015 [cited 2018 Mar 3];43(3):206-21. Available from: https://www.ncbi.nlm.nih.gov/pmc/articles/PMC4653815

13. Nicolle LE. Catheter associated urinary tract infections. Antimicrob Resist Infect Control [Internet]. 2014 [cited 2018 Mar 3];3:23. Available from: https://www.ncbi.nlm.nih.gov/pmc/articles/PMC4114799/

14. Durant DJ. Nurse-driven protocols and the prevention of catheter-associated urinary tract infections: a systematic review. Am J Infect Control. 2017;45(12):1331-41.

15. Daud-Gallotti RM, Costa SF, Guimaraes T, Padilha KG, Inoue EN, Vasconcelos TN, et al. Nursing workload as a risk factor for healthcare associated infections in ICU: a prospective study. PLoS One [Internet]. 2012 [cited 2018 Mar 3];7(12):e52342. Available from: https://www.ncbi.nlm.nih.gov/pmc/articles/PMC3531467/

16. Conselho Federal de Enfermagem (COFEN). Parecer normativo para atuação da equipe de enfermagem em sondagem vesical [Internet]. Brasília, DF: COFEN; 2013 [citado 2018 fev. 19]. Disponível em: http://novo.portalcofen.gov.br/wp-content/uploads/2014/01/ANEXOPARECER-NORMATIVO-PARA-ATUACAO-DA-EQUIPE-DE-ENFERMAGEM-EM-SONDAGEM-VESICAL1.pdf

17. Lehman SM, Donlan RM. Bacteriophage-mediated control of a two-species biofilm formed by microorganisms causing catheter-associated urinary tract infections in an in vitro urinary catheter model. Antimicrob Agents Chemother [Internet]. 2015 [cited 2018 Mar 8];59(2):1127-37. Available from: https://www.ncbi.nlm.nih.gov/pmc/articles/PMC4335898/

18. Ternavasio-de La Vega HG, Ventura AB, Castaño-Romero F, Sauchelli FD, Acosta AP, Rodríguez AFJ, et al. Assessment of a multi-modal intervention for the prevention of catheter-associated urinary tract infections. J Hosp Infect. 2016;94(2):175-81. Erratum in: J Hosp Infect. 2017;97(3):318. DOI: 10.1016/j.jhin.2016.07.011.

19. Carraro-Eduardo JC, Alves DS, Hinden IE, Toledano IP, Freitas SG, Mondino PJ, et al. Urinary tract infection and indwelling urinary catheters: prospective study in gynecological surgery with antibiotic prophylaxis. Sao Paulo Med J [Internet]. 2015 [cited 2018 Mar 5]; 133(6):517-20. Available from: http://www.scielo.br/pdf/spmj/v133n6/1516-3180-spmj-2014-9071412.pdf

20. Clayton JL. Indwelling urinary catheters: a pathway to health care-associated infections. AORN J. 2017; 105(5):446-52. DOI: 10.1016/ j.aorn.2017.02.013

21. Regagnin DA, Alves DSS, Cavalheiro AM, Camargo TZS, Marra AR, Victor ES, et al. Sustainability of a program for continuous reduction of catheter-associated urinary tract infection. Am J Infect Control. 2016;44(6):642-6. 